\title{
PEMBELAJARAN BAHASA ARAB BERBASIS TEKNOLOGI INFORMASI DAN KOMUNIKASI DI KEDIRI
}

\author{
Oleh Taufiq Anshori, SS, M.Pd \\ E-mail taufiq86anshori@gmail.com
}

\begin{abstract}
This study aimed to analyze the design of ICT-based Arabic learning model. This study was designed to find the best model of ICT-based Arabic learning. This study proposed that the integration of various fields of studies with ICT, including Arabic language learning, is undeniably vital to be enhanced in this digital era. However, the constraints experienced by some institutions, especially the educators, have not had a clear format of the use of ICT in the integration effort of the both disciplines. This study applied research and development model with a qualitative research method. This research was conducted through three phases, i.e. introduction, development and implementation. The research sampling technique was purposive sampling. The data were collected by conducting observation, interview and documentation. The data were analyzed using the techniques developed by Miles and Huberman. The results showed that the design of ICTbased Arabic learning model can be developed at MTs Negeri KEDIRI was the al-Hâsûb alIttishâlî model, i.e. a communicative computer-based Arabic learning model. In this model, the materials and other learning tools are designed using a computer program. Through this kind of learning models, a teacher served as learning motivator and mediator elaborating the materials that need clarification for the learners.
\end{abstract}

Keywords : learning model, Arabic learning, information communication technologies

\begin{abstract}
Abstrak
Penelitian ini bertujuan untuk menganalisis desain model pembelajaran bahasa Arab berbasis TIK. Penelitian ini didesain untuk menemukan model pembelajaran bahasa Arab berbasis TIK. Penelitian ini berasumsi bahwa integrasi berbagai bidang studi dengan TIK, termasuk pembelajaran bahasa Arab, sangat penting dikembangkan di era digital ini. Namun, kendala yang dialami oleh beberapa lembaga pendidikan, khusunya pendidik, belum memiliki format yang jelas dalam menggunakan TIK dalam upaya integrasi dua bidang keilmuan tersebut. Penelitian ini menggunakan research and development dengan metode penelitian kualitatif. Penelitian ini dilakukan melalui tiga tahap: pendahuluan, pengembangan dan pelaksanaan. Sampel penelitian yang digunakan adalah purposive sampling. Teknik pengumpulan data dilakukan dengan observasi, wawancara dan studi dokumentasi. Data dianalisis dengan menggunakan teknik yang dikembangkan oleh Miles dan Hubermas. Hasil penelitian menunjukkan bahwa desain model pembelajaran bahasa Arab berbasis TIK yang dapat dikembangkan di MTs Negeri KEDIRI adalah
\end{abstract}


model "al-hâsûb al-ittishâl̂̂", yakni model pembelajaran bahasa Arab komunikatif berbasis komputer. Dalam model ini materi dan perangkat pembelajaran lainnya didesain dalam program komputer. Melalui model tersebut guru berfungsi sebagai motivator learning bagi peserta didik dan mediator pada materi-materi yang memerlukan penjelasan di kalangan peserta didik.

Kata Kunci : model pembelajaran, pembelajaran bahasa Arab, teknologi informasi dan komunikasi

\section{Pendahuluan}

Keterampilan ber-bahasa Arab pada peserta didik berkaitan dengan model dan strategi yang digunakan oleh pendidik. Selama ini pendidik kurang menyesuaikan dengan jiwa dan karakter peserta didik. Inilah yang menyebabkan belum terwujudnya keterampilan ber-bahasa Arab pada peserta didik. Pada umumnya Peserta didik pada tingkat Madrasah Tsanawiyah telah akrab dengan komputer. Disandingkan dengan teknologi informasi dan komunikasi ini dapat menunjang kreatifitas pendidik untuk melaksanakan proses pembelajaran sesuai dengan jiwa dan kebutuhan mereka

Sistem pembelajaran mengalami perkembangan secara terus-menerus seiring dengan perkembangan yang terjadi pada disiplin ilmu bahasa, ilmu pendidikan, dan arus perkembangan zaman. Lebih dari itu hasil-hasil penelitian dalam bidang pengajaran bahasa itu sendiri juga memberikan kontribusi pada lahirnya pendekatan dan metode baru dalam pengajaran bahasa. ${ }^{1}$ Dewasa ini pengajaran bahasa Inggris sebagai bahasa dunia adalah yang paling banyak peminatnya. Sedangkan pengajaran bahasa Arab lebih banyak berperan sebagai adopsiator sehingga seringkali tertinggal satu langkah dibandingkan pengajaran bahasa Inggris. Demi keberhasilan suatu program pendidikan, pembelajaran adalah salah satu model atau komponen penting sekaligus memerankan peran yang besar didalamnya.Pada dasarnya, model dimaksudkan menjadi payung utama untuk spesifikasi dan interelasi antara teori dan praktik. Apa yang dipahami siswa merupakan korpus dari model yang digunakan, meskipun terdapat sejumlah perbedaan model dalam belajar bahasa, teori bahasa tetap berasumsi bahwa bahasa adalah sebuah sistem kebiasaan dalam komunikasi.

Seiring dengan perkembangan zaman di era kemajuan teknologi informasi dan komununikasi ini dunia pendidikan butuh konsep pendidikan yang sinergi dengan kemajuan teknologi termasuk pembelajaran bahasa. Penelitian telah membuktikan bahwa model pembelajaran yang didukung dengan pemanfaatan media pembelajaran menunjukan dampak

\footnotetext{
${ }^{1}$ Abdurrahman Faridi, "Inovasi Pembelajaran Bahasa Inggris Berbasis ICT dalam Rangka Meningkatkan Mutu Pendidikan", dalam Journal Lembaran Ilmu Kependidikan, Jilid 38, No. 1, Juni 2009, h. 59.
} 
yang sangat signifikan terhadap kemampuan pembelajar memahami materi dibandingkan dengan system conventinal instruction. ${ }^{2}$

Pembelajaran yang hanya berbentuk ceramah akan membuat peserta didik memahami materi hingga 5\%. Jika model pembelajaran berkembang dengan mereka membaca, presentasi akan meningkat menjadi 10\%, berturut-turut audiovisual, demontsrasi, diskusi, latihan, dan saling mengajar akan mencapai mulai dari $20 \%$ hingga $80 \% .^{3}$

Schramm mengemukakan bahwa bahwa materi pembelajaran sangat dipengaruhi oleh isi dan model instruksional serta jenis teknologi yang digunakan. ${ }^{4}$ Di sisi lain, Clark mengatakan bahwa penggunaan teknologi (komputer multimedia) dalam pembelajaran sangat membantu penyiapan materi secara efisien dan efektif. ${ }^{5}$ Komputer dapat berperan ganda dalam pembelajaran, termasuk pembelajaran bahasa Arab.

Untuk Penggunaan komputer, pembelajaran memang sudah dimulai sejak tahun 60-an ${ }^{6}$, akan tetapi komputer hanya berperan sebagai tutor yang menyajikan latihan-latihan, tetapi tidak dapat memberikan penilaian (feedback) dan pendekatan berupa reward dan punishment yang membantu peserta didik untuk termotivasi dalam belajar. Bahkan adanya komputeruntuk belajar bahasa di berbagai sekolah belum mampu meningkatkan motivasi mempelajari bahasa Arab di kalangan peserta didik. Keberadaan komputer juga belum bisa membuat guru untuk merancang pembelajaran bahasa Arab secara kreatif dan inovatif. Komputer hanya dimanfaatkan untuk mata pelajaran yang bersifat umum seperti matematika, bahasa Indonesia, bahasa Inggris dan mata pelajaran umum lainnya, sementara untuk pembelajaran bahasa Arab keberadaan komputer tersebut belum dimanfaatkan oleh guru dan peserta didik.

Secara fundamental, pembelajaran berbasis TIK yang dalam penerapannya sangat mengutamakan penggunaan teknologi seperti komputer, sehingga lebih dikenal dengan istilah pembelajaran berbasis komputer atau Computer Based Instruction (CBI) ini merupakan sebuah proses pembelajaran yang menggunakan komputer untuk menyajikan materi pembelajaran dengan memberikan kesempatan kepada peserta didik untuk berpartisifasi secara aktif dan merespon aktivitas siswa. ${ }^{7}$ Bahkan pendapat yang lebih dalam dikemukakan oleh Made Wane, pembelajaran berbasis TIK yang disajikan melalui komputer membuat kegiatan proses belajar mengajar menjadi lebih menarik dan menantang bagi peserta didik. ${ }^{8}$

Kemampuan seorang guru dalam berbahasa tidak menjamin bahwa dia terampil dalam mengajarkan bahasa tersebut. Seorang guru bahasa Arab seharusnya memiliki setidaknya tiga keterampilan, yakni: 1) Kemahiran berbahasa Arab, 2) Pengetahuan tentang bahasa dan budaya

\footnotetext{
${ }^{2}$ P. Hubbard, Learner Training for Effective Use of CALL. State College PA: Center for Advance Language Proficiency and Education and Research,2006), h. 98.

${ }^{3}$ Yusring Sanusi Baso, Program Multimedia Bahasa Arab, (Padang: Prosiding PINBA IMLA, 2013), h. 221.

${ }_{5}^{4}$ Wilbur Schramm, Asas-asas Komunikasi Antar Manusia, Terj. Agus Setiadi, (Jakarta: LP3ES, 1977), h. 86.

${ }^{5}$ Richard E. Clark, "Reconsidering Research on Learning from Media”, dalam Journal JSTOR, 1983, Vol. 53, No. 4. pp. 445-459.
}

${ }^{6}$ Maysa' Abu Syanab, "Tiknulujia Ta'allum al-Lughah al-'Arabiyah”, dalam Journal al-Adab wa al-Tarbiyah, Sudan, Vol. 2, No. 32, 2007), h. 66. 
Arab, 3) Keterampilan mengajar bahasa Arab. ${ }^{9}$ Dengan ketiga syarat tersebut dihubungkan dengan teknologi, seorang guru dituntut terampil memanfaatkan berbagai media teknologi dalam mengajarkan bahasa Arab. Kemampuan seorang guru membuat media dan menggunakannya merupakan bagian dari keterampilan mengajar bahasa.

Berdasarkan hasil wawancara dengan salah seorang guru bahasa Arab, media komputer belum dimanfaatkan secara maksimal dalam mengajarkan bahasa Arab, pembelajaran bahasa Arab yang dilakukan selama ini mengacu kepada RPP yang disusun dari jauh hari dan tidak menggunakan komputer sebagai medianya. ${ }^{10}$ Hal ini menurutnya disebabkan belum adanya pedoman khusus yang dapat dijadikan sebagai acuan untuk mengintegrasikan TIK dalam dan dengan pembelajaran bahasa Arab. Yogi yang merasakan bahwa belajar bahasa Arab sebagai hal yang membosankan karena sistem pembelajarannya hanya bersumber dari LKS (Lembar Kerja Siswa) yang diberikan setiap awal semester, sementara media TIK belum dimanfaatkan untuk itu. Hal ini berbeda dengan pengajaran pada mata pelajaran lain yang telah memanfaatkan TIK dalam proses pembelajaran. ${ }^{11}$ Dalam hal ini ditegaskan bahwa dia telah terbiasa mengetik dengan menggunakan bahasa Inggris, namun bagaimana cara mengetik berbahasa Arab sama sekali belum pernah dipelajarinya.

Pemanfaatan TIK tidak terlepas dari problematika,maka dari itu diperlukan suatu upaya untuk menghadapi hambatan yang akan muncul dalam penerapan pembelajaran bahasa Arab berbasis TIK di MTs bagi guru. Terlebih lagi, jika kita meninjau dari aspek kemampuan pembelajaran guru selama ini yang memiliki kecenderungan tidak berani mencoba melakukan inovasi penerapan model pembelajarannya, maka tentu akan menjadi problematika awal bagi mereka dalam menerapkan pembelajaran bahasa Arab berbasis TIK tersebut. Kondisi ini juga semakin dipersulit dengan belum tersedianya pedoman khusus pelaksanaan pembelajaran bahasa Arab berbasis TIK tersebut bagi guru bahasa Arab. Belum tersedianya pedoman khusus pelaksanaan pembelajaran bahasa Arab berbasis TIK bagi guru merupakan indikasi belum terintegrasinya secara efektif antara dunia yang dekat kepada peserta didik dengan proses pembelajaran bahasa Arab.

\section{Diskusi dan Analisis Kebutuhan terhadap Model Pembelajaran Bahasa Arab Berbasis TIK}

Untuk mengetahui model pembelajaran yang dibutuhkan lembaga pendidikan jenjang MTs peneliti melakukan kajian terhadap beberapa aspek, yakni kurikulum dan perangkat pembelajaran yang digunakan, kesulitan yang dihadapi peserta didik dan kendala yang dialami pendidik dalam pembelajaran bahasa Arab. Berdasarkan hasil observasi, dokumentasi dan

\footnotetext{
${ }^{9}$ Abdul 'Aziz Ibrahim al-'Ushaili, Asâsiyat Ta'lîm al-Lughah al-'Arabiyah Li an-Nâthiqîn bi Lughât Ukhra, (Riyadh:Jami'ah al-Imam Muhammadbin Su'ud al-Islamiyah, 1423 H), h. 268.

${ }^{10}$ Qamaruz Zaman, Guru Bahasa Arab MTs Negeri Durian Tarung, (Wawancara, 20 Maret 2015)

11 Yogi Syaputra, Peserta Didik MTs Negeri Durian Tarung Padang, (Wawancara: 20 Maret 2015)
} 
wawancara di tiga MTs Negeri di Kota Kediri, yakni MTs Negeri Puncu, MTs Negeri Model Pare dan MTs Negeri 3 Kediri, diketahui bahwa ketiga lembaga pendidikan tersebut menggunakan dua macam kurikulum, yaitu Kurikulum Tingkat Satuan Pendidikan dan Kurikulum 2013. Keanekaragaman kurikulum yang dipakai setidaknya mempengaruhi proses pembelajaran yang akan dilakukan dan menuntut kearifan pendidik dalam menyesuaikan segala aspek pembelajaran yang sesuai dengan dunia peserta didik. Pelaksanaan pembelajaran yang ada di ketiga MTs Negeri sebagaimana dijelaskan di atas menggunakan dua kurikulum. Kedua jenis kurikulum tersebut dalam pelaksanaannya diawali dengan menyiapkan perangkat pembelajaran seperti program tahunan, program semester, program bulanan, program mingguan dan membuat rencana pelaksanaan pembelajaran. Hal ini sesuai dengan pernyataan Refly Anwar, bahwa masing-masing guru tidak hanya guru bahasa Arab dituntut untuk dapat menyiapkan semua perangkat pembelajaran. ${ }^{12}$ Pernyataan senada juga diungkapkan oleh Kamarul Zaman bahwa sebelum mulai program pembelajaran seluruh guru diharuskan mengumpulkan perangkat pembelajaran dan diserahkan kepada wakil kepala sekolah bidang kurikulum, tujuannya tidak lain untuk menjaga kulitas proses pembelajaran. ${ }^{13}$

Ketersediaan perangkat pembelajaran tersebut juga diperkuat oleh pernyataan Nindita yang mengatakan bahwa guru bahasa Arab selalu menjelaskan terlebih dahulu apa yang diharapkan ketika mempelajari sebuah materi pembelaran. ${ }^{13}$ Berdasarkan analisis perangkat pembelajaran seperti rencana pelaksanaan pembelajaran diketahui banyak materi pembelajaran yang membutuhkan pengembangan melalui integrasi dengan Teknologi Informasi dan Komunikasi (TIK), seperti materi aspek pengucapan huruf yang benar, materi percakapan dan yang tidak kalah pentingnya adalah tadrîb li mahârat al-istimâ ${ }^{14}$

Selain ketersedian rencana pelaksanaan pembelajaran, tenaga pendidik juga dituntut agar dapat menyiapkan media pembelajaran yang dapat menunjang kelancaran dan membantu peserta didik untuk lebih mudah memahami materi pembelajaran. Dalam pembelajaran bahasa Arab, guru dituntut untuk membuat media seperti gambar yang dapat membantu pemahaman peserta didik terhadap materi yang diajarkan.

Hegemonitas peserta didik pada lembaga pendidikan ini memiliki pengaruh terhadap proses pembelajaran khususnya mata pelajaran keagamaan tanpa terkecuali bahasa Arab. Peserta didik yang memiliki pengetahuan awal tentang bahasa Arab setidaknya telah mengenal dan mengetahui makna beberapa kosa kata yang sering digunakan dalam kehidupan sehari-hari. Berbeda dengan peserta didik yang tidak memiliki pengetahuan dasar tentang bahasa Arab, mereka seakan merasakan sesuatu yang asing ketika mempelajari bahasa Arab.

\footnotetext{
${ }^{12}$ Refly Anwar, Guru Bahasa Arab MTs NegeriLubuk Buaya, (Wawancara: 09 September 2015).

${ }^{13}$ Nindita Salsabila, Siswi MTs Durian Tarung (Wawancara: 14 September 2015)

${ }^{14}$ Dokumentasi, Rencana Pelaksanaan Pembelajaran, (Studi Dokumentasi, 14 September 2015).
} 
Berdasarkan hasil observasi peneliti terhadap peserta didik MTs Negeri Kediri terlihat bahwa sebagian peserta didik memiliki kemauan yang besar dalam belajar bahasa Arab. Hal ini terbukti dengan mendengarkan penjelasan guru, memperhatikan, dan melakukan perintah guru untuk menjawab pertanyaan, serta mengerjakan tugas sekolah dan rumah dengan baik, kemudian mencoba mempraktekkan berbicara bahasa Arab sesama teman meskipun masih jauh dari tata bahasa yang benar. Namun, selain itu, terdapat juga sebagian peserta didik tidak memperhatikan pelajaran bahasa Arab dengan baik, terlihat banyaknya peserta didik yang berbicara dengan teman sebangku, malas dalam mengerjakan tugas sekolah dan rumah yang diberikan guru. ${ }^{15}$

Selain beberapa data di atas, terlihat juga bahwa para peserta didik yang mengikuti pelajaran bahasa Arab mengalami berbagai kesulitan, mulai dari kesulitan dalam mengungkapkan kalimat-kalimat bahasa Arab, mempraktikkan ungkapan-ungkapan berbahasa Arab hingga upaya untuk menjawab latihan-latihan yang ada dalam Lembar Kerja Siswa, peserta didik terlihat kesulitan untuk mengerjakan berbagai model latihan yang terdapat di dalamnya.

Dari beberapa data di atas, diketahui bahwa peserta didik di ketiga MTs Negeri yang ada di Kediri membutuhkan sebuah model pembelajaran yang dapat mereka pahami, gunakan dan kerjakan berbagai model latihan. Model itu tentunya adalah sebuah model yang mencakup semua materi yang akan mereka pelajari dalam dua semester. Karena mereka mengalami kesulitan dalam mengungkapkan kalimat-kalimat berbahasa Arab, maka model yang seharusnya dirancang juga dilengkapi dengan audio yang dapat didengarkan oleh peserta didik. Model yang akan dibuat juga diharuskan memuat berbagai media gambar yang mengantarkan pemahaman peserta didik terhadap materi pembelajaran.

\section{Model yang Ditawarkan}

Berdasarkan analisis kebutuhan pendidik dan peserta didik sebagaimana yang dijelaskan di atas, peneliti meranc ang sebuah model pembelajaran bahasa Arab yang kemudian diistilahkan dengan al-hâsûb al-ittishâlî. Inisiatif pemberian nama dan penyebutan al-hâsûb alittishâlî merupakan pemikiran dari tim peneliti. Adapun alasan yang mendasarinya ialah karena nuansa model yang dibuat mengarah kepada sistem komputer yang dapat berinteraksi dan pembelajar fokus dalam mendengarkan, memperhatikan, mengungkapkan kem-bali, merespon, mengerjakan latihan-latihan, dengan sendirinya mereka akan mengetahui sendiri tingkat kemampuan yang mereka miliki berdasarkan skor nilai yang dikeluarkan oleh sistem komputer.

Model al-ĥâsûb al-ittishâlî didefinisikan peneliti sebagai "komputer yang komunikatif”. Maksudnya adalah materi-materi yang berkaitan dengan kemampuan menyimak, kemampuan berbicara dan kemampuan membaca dilengkapi dengan audio yang membantu peserta didik untuk mengetahui cara pelafalan, cara membaca dan intonasi yang baik dan benar.

\footnotetext{
${ }^{15}$ Observasi, Proses Pembelajaran Bahasa Arab di MTs Negeri, (15 Juni 2015).
} 
Materi seperti kosakata didukung audio yang jika menu perintahnya diklik maka dengan sendirinya akan mengeluarkan audio dan animasi tentang kosakata yang dimaksudkan, seperti jika pengguna mengklik kata السبورةmaka model ini akan mengeluarkan suara yang mengungkapkan kata tersebut dan disertai dengan animasi gambar sebuah papan tulis. Begitu juga dengan sejumlah kosa kata lainnya yang jika diperlakukan sama maka akan keluar audio yang mengungkapkan kata tersebut disertai dengan animasi tentang kata yang diklik.

Selain didukung dengan audio, materi yang berkaitan percakapan dalam model ini juga didukung dengan audio visual dalam bentuk percakapan antardua orang, percakapan antar tiga orang bahkan percakapan antar empat orang. Peran pelaku dalam audio visual yang dirancang juga disesuaikan dengan porsi, profesi dan posisinya dalam percakapan. Misalnya ungkapan yang berkaitan dengan aktivitas peserta didik diungkapkan oleh siswa, ungkapan yang berkaitan dengan pembicaraan pendidik diperankan oleh guru dan begitu seterusnya dalam percakapanpercakapan lainnya. Muatan model yang didukung dengan audio visual memberikan peluang kepada peserta didik untuk dapat mempraktikkan bersama temannya sebagaimana yang terdapat dalam model al-hââub al-ittishâlî.

Sementara aspek evaluasi dan latihan yang terdapat dalam model al-hîasûb al-ittishâlî dirancang agar peserta didik dapat mengerjakan beberapa variasi contoh latihan. Khusus latihan yang sifatnya objektif jika peserta didik mengerjakannya maka mereka akan dapat mengetahui tingkat kemampuan mereka secara objektif dan fleksibel. Hal ini dikarenakan sifat latihan yang disajikan disertai dengan batas waktu dan koreksitas dari sistem yang dirancang. Jika batas waktu untuk mengerjakan beberapa soal telah habis maka dengan sendirinya pengguna tidak dapat memperbaiki kembali jawaban mereka apalagi mengerjakan yang belum terjawab, dan sistem akan mengeluarkan skor nilai yang diraih, jika tingkat kebenaran mencapai 100\% maka sistem akan mengeluarkan animasi pujian yang disertai dengan tulisan sil, dan jika tingkat kebenaran mencapai $75 \%$ sistem juga akan mengeluarkan animasi yang disertai dengan tulisan جيد, namun jika tingkat ketuntasan di bawah 75\% maka sistem akan mengeluarkan animasi yang bersifat rasa kasihan dan disertai dengan tulisan عليك أن تتكلم أيضا

Berdasarkan hasil validasi tim ahli dan hasil uji coba serta penilaian peserta didik terhadap model yang ditawarkan, dapat dikatakan bahwa model yang dirancang ini dapat dikembangkan untuk kemudian dijadikan sebagai sumber maupun media pembelajaran bahasa Arab. Karena baik penilaian pakar dan penilaian peserta didik terlihat positif dengan keberadaan model yang dirancang.

Model ini dikatakan sebagai sumber belajar ialah karena muatan-muatan yang terdapat di dalamnya mencakup materi pembelajaran bahasa Arab untuk kelas VII yang selama ini berada dalam buku cetak dan lembar kerja siswa. Dengan keberadaan model al-hâsûb alittishâlî yang dirancang tersebut baik pendidik maupun peserta didik dapat beralih dari buku cetak kepada sumber yang berada dalam VCD dan dioperasikan melalui komputer. 
Sementara itu, ketika model ini dapat dijadikan sebagai media pembelajaran ialah karena dalam model ini memuat beberapa gambar (picture) dan audio yang dapat mendukung proses pembelajaran, bahkan pendidik yang menggunakan model al-hâsûb al-ittishâlî dalam tugas mengajar mereka tidak disibukkan membuat dan mempersiapkan media pembelajaran dan menetukan metode pembelajaran. Mereka hanya berperan sebagai motivator dan fasilitator bagi peserta didik.

Adapun muatan model al-hâsûb al-ittishâlî dalam kaitannya dengan pencapaian keterampilan berbahasa Arab, dapat dijelaskan sebagaimana berikut ini:

\section{Keterampilan Menyimak}

Materi yang dimuat dalam model ini ialah meliputi materi pembelajaran bahasa Arab yang diajarkan kepada kelas VII MTs Negeri. Hal ini tidak terlepas dari kurikulum yang digunakan pada kelas VII adalah kurikulum 2013 yang mengharuskan adanya integrasi keilmuan dengan saintifik. Materi-materi tersebut berkaitan dengan materi yang diajarkan pada semester I dan semester II. Muatan dari materi ajar ini meliputi kosakata dari masingmasing topik pembicaraan, contoh percakapan yang benar, bahan bacaan untuk peserta didik dari masing-masing topik, pola-pola kalimat, disertai kisi-kisi soal yang langsung dapat dijawab oleh peserta didik dan mereka dapat mengetahui nilai atau kemampuan mereka dengan batas waktu yang ditentukan.

Dalam rangka membantu peserta didik memiliki keterampilan menyimak, model pembelajaran bahasa Arab al-hâsûb al-ittishâlî yang dirancang memuat:

a) Percakapan dengan bahasa Arab, dalam percakapan tersebut dibuat menu pengaturan yang dapat diperlambat cara pengucapannya serta dapat diulang oleh stakholder. Hal ini memungkinkan mereka untuk dapat menyimak apa yang diutarakan oleh sang penutur sesuai dengan maksud pembicaraannya.

b) Bahasa Arab dijadikan sebagai bahasa pengantar dalam proses pembelajaran. Dalam model al-hâsûb al-ittishâlî program yang dibuat ialah di mana bahasa pengantar untuk setiap materi pembelajaran menggunakan bahasa Arab. Hal ini mengarahkan pendidik agar memberikan motivasi kepada peserta didik untuk saling bertukar pikiran di antara mereka dengan menggunakan bahasa Arab.

c) Model ini memperkenalkan beberapa contoh penutur bahasa Arab sesuai dengan topik dan tipe pembicaraannya. Hal ini menguntungkan bagi peserta didik agar mereka mampu untuk membedakan cara mengungkapkan bahasa Arab sesuai dengan konteks dan tipe pembicaraan, serta membantu peserta didik agar mampu memahami situasi berlangsungnya percakapan.

d) Model al-hâsûb al-ittishâlî juga memberikan kesempatan kepada peserta didik agar mereka dapat belajar secara mandiri, mendengarkan kembali materi-materi pembelajaran di luar kelas. Karena dalam model yang dirancang tersebut dapat digunakan oleh peserta didik secara sendiri baik di dalam kelas maupun di luar kelas. 
e) Dalam model al-hâsûb al-ittishâlî juga dirancang sebuah contoh evaluasi menyimak berupa adanya audio yang dapat ditekan sendiri dan mereka bisa memilih di bawahnya beberapa kata yang disediakan untuk dipilih. Hal ini mengantarkan peserta didik untuk mampu mengetahui apakah jawaban mereka tersebut sesuai dengan apa yang mereka dengarkan.

Penjelasan di atas mengindikasikan bahwa model pembelajaran bahasa Arab al-hâsûb al-ittishâlî memberikan peluang bagi pendidik untuk dapat menjadi motivator dan fasilitator dalam mengajarkan bahasa Arab kepada peserta didik. Model ini juga membantu peserta didik untuk memiliki kemampuan menyimak bahasa Arab secara baik dan benar, kemampuan peserta didik dalam menyimak merupakan suatu keharusan dan amat penting, karena salah satu kendala yang dihadapi pendidik dalam mengajarkan bahasa Arab ialah keterampilan menyimak.

\section{Keterampilan Berkomunikasi}

Salah satu kemampuan berbahasa yang harus dicapai ialah keterampilan berbicara. Ada beberapa konsep dasar yang seharusnya dipahami oleh pendidik sebelum mengajarkan bahasa kedua kepada peserta didik, yakni: a)berbicara dan menyimak adalah dua kegiatan resiprokal, b)berbicara adalah proses berkomunikasi individu, c)berbicara adalah ekspresi kreatif, d)berbicara adalah tingkah laku, e)berbicara dipengaruhi kekayaan pengalaman, f) berbicara sarana memperluas cakrawala, dan g)berbicara adalah pancaran pribadi.

Sesuai dengan konsep dasar di atas, model pembelajaran bahasa Arab al-hââûb alittishâlî dirancang dalam rangka membantu peserta didik memiliki keterampilan berkomunikasi dengan bahasa Arab secara baik dan benar sebagaimana berikut:

a) Pengucapan kosakata serta kalimat dalam model yang dirancang dipadukan dengan perintah اسمع وأعد(dengarkan dan ulangi). Maksudnya dalam hal ini ialah bahwa aktivitas pembelajaran menuntut keaktifan peserta didik untuk mendengarkan rekaman dan kemudian mengulangi rekaman tersebut.

b) Dalam model ini juga dibuat beberapa kata tanpa adanya audio. Hal ini dimaksudkan agar peserta didik melihat kata-kata tersebut untuk kemudian melafalkannya sesuai dengan apa yang tertulis. Hal ini memberikan pelatihan kepada mereka agar mampu mengidentifikasi kata.

c) Model al-hââhb al-ittishâlî juga menyajikan beberapa gambar tanpa adanya tulisan bahasa Arab dan cara membacanya. Keberadaan gambar ini diarahkan untuk melatih kemampuan berkomunikasi di kalangan peserta didik melalui apa yang ada di sekitar mereka dengan mengungkapkannya secara bahasa Arab.

d) Dalammembantukemampuan berkomunikasi di kalangan peserta didik, model al-hâasûb al-ittishâlı̂ juga menyediakan permainan kartu yang dapat dimainkan oleh peserta didik baik secara individual maupun kelompok. Misalnya, kartu yang berisi kata-kata 
tertentu dengan pentunjuk mencari benda aslinya, kartu yang berbicara tentang sesuatu dengan bermain peran.

e) Sebagaimana dalam hal menyimak, model ini juga membantu peserta didik untuk mampu berkomunikasi dengan bahasa Arab sesuai dengan konteks dan tipe pembicaraan, membedakan penggunaan nada tinggi, nada rendah, intonasi sedih, ungkapan gembira dan lain sebagainya. Hal ini tidak terlepas dari terdapatnya beberapa contoh dari tipe dan konteks pembicaraan.

Dari beberapa ciri model al-hââub al-ittishâlî yang dijelaskan di atas dapat dipahami bahwa model ini dapat membantu peserta didik untuk mampu berkomunikasi dengan bahasa Arab secara baik dan benar. Evaluasi yang diberikan dalam membantu keterampilan berkomunikasi ini ialah lebih mengarah pada latihan mengungkapkan kata dan kalimat.

\section{Kemampuan Membaca}

Model pembelajaran al-hââûb al-ittishâlî juga dapat membantu peserta didik memiliki keterampilan membaca bahasa Arab secara baik. Namun, membaca yang dimaksud di sini bukanlah membaca dalam menentukan baris dan posisi kata dalam sebuah kalimat, tetapi keterampilan membaca yang mungkin dapat dicapai dengan model ini ialah reading for information, yakni membaca untuk memperoleh informasi.

Hal itu tidak terlepas dari materi-materi bacaan pun yang telah diatur sedemikian rupa sesuai dengan mater-materi pembelajaran yang ada. Kebenaran cara membaca tetap menjadi perhatian namun bukanlah hal utama. Yang paling utama adalah bagaimana peserta didik mampu mengenali teks bacaan, memaknai dan menggunakan kosa kata yang terdapat di dalam bacaan, memahami informasi yang terdapat dalam bacaan secara eksplisit dan implisit, memahami makna konseptual, memahami nilai komunikatif dari suatu kalimat, menginterpretasikan bacaan, membedakan gagasan utama dan gagasan penunjang, menentukan hal-hal pentuk untuk dijadikan rangkuman.

Dengan tujuan yang disebutkan di atas, maka dalam model pembelajaran bahasa Arab al-hââub al-ittishâlî keterampilan membaca dibuat dengan:

a) Materi bacaan disarikan dari materi kosa kata dan percakapan yang ada sebelumnya.

b) Dari materi bacaan tersebut peserta didik dituntut agar mampu memaknai dan menggunakan kosa kata penting yang ada di dalamnya berkaitan dengan materi pokok.

c) Mereka juga diharapkan mampu mengungkapkan informasi yang terdapat dalam materi bacaan.

d) Dalam latihan, peserta didik diharapkan mampu merangkum kategori kata yang terdapat dalam bacaan. Misalnya, mereka diharapkan mampu mengumpulkan beberapa kata yang berkaitan dengan perlengkapan sekolah, peralatan rumah tangga, anggota keluarga, SDM di sekolah dan lain-lain. 
e) Peserta didik juga diharapkan mampu mendeskripsikan kembali isi bacaan. Untuk itu, dalam model al-hââub al-ittishâlî salah satu aspek yang dievaluasi ialah bagaimana peserta didik mampu mengutarakan ide pokok serta makna secara umum materi bacaan yang disediakan.

Keterampilan membaca dalam model al-hââub al-ittishâlî adalah keterampilan yang diarahkan untuk dapat membaca dengan baik, memahami arti kata atau kalimat, mengungkapkan gagasan yang terdapat dalam teks bacaan. Untuk itu, materi bacaan tidak terlepas dari materi-materi yang ada pada pencapaian keterampilan menyimak dan keterampilan berbicara. Dengan keterkaitan antara materi keterampilan menyimak, keterampilan berbicara dan keterampilan membaca ini membantu peserta didik agar dapat membaca materi atau teks qirâ'ah secara baik dan benar.

\section{Keterampilan Menulis}

Keterampilan menulis merupakan salah satu kemampuan yang harus dimiliki insan yang belajar bahasa. Keterampilan ini merupakan keterampilan yang paling tinggi tingkat kesulitannya bagi peserta didik dibandingkan tiga keterampilan berbahasa lainnya. Terlebih lagi apabila dikaitkan dengan kemampuan menulis dalam bahasa lain seperti bahasa Arab, perbedaan budaya menuliskan huruf Latin dengan huruf Arab tetap menjadi sebuah aspek kesulitan tersendiri bagi peserta didik.

Penulisan bahasa Arab yang diawali dari kanan ke kiri tetap juga menjadi sebuah momok yang membuat peserta didik sulit untuk mencapai keterampilan menulis. Artinya, dalam hal ini, tantangan bagi pendidik untuk mewujudkan peserta didik yang terampil menulis bahasa Arab sangat berat, karena menuliskan ide-ide pikiran saja berat atau sulit, apalagi mereka menuliskan kembali kalimat-kalimat yang terdapat dalam buku ke dalam catatan.

Dalam rangka mencapai keterampilan menulis sebagaimana yang dijelaskan di atas, model pembelajaran al-hââub al-ittishâlî memberikan arah pembelajaran kitâbah sebagaimana yang telah dirancang ialah sebagai berikut:

a) Mencari kata Maksudnya adalah peserta didik diberikan semacam latihan untuk mencari pasangan kata yang tepat terhadap sebuah kalimat, mencari sambungan kata yang benar untuk sebuah kalimat, mencari kata yang benar secara penulisannya, dan beberapa jenis pencarian kata lainnya.

b) Membuat teka teki silang

Dalam model ini juga digambarkan materi pembelajaran kitâbah yang mengarahkan peserta didik untuk mampu menjawab teka teki silang. Jenis ini dimaksudkan untuk melatih inteligensi dan daya ingat peserta didik terhadap materi yang sudah dipelajari.

c) Elaborasi 
Yakni peserta didik dituntut untuk dapat mengelaborasi sebuah kata menjadi sebuah kalimat, atau meelaborasi sebuah pernyataan menjadi sebuah pertanyaan, mengelaborasi pertanyaan menjadi sebuah pernyataan.

d) Deskripsitas

Dalam model al-hââûb al-ittishâlî juga diberikan semacam latihan kepada peserta didik untuk dapat mendeskripsikan sesuatu menjadi kalimat. Misalnya, model ini menyediakan sebuah gambar, dari gambar tersebut peserta didik diharapkan mampu mendeskripsikan apa, siapa, bagaimana, kapan, di mana keberadaan gambar tersebut.

e) Mengarang bebas

Al- $\underline{H} \hat{a} s \hat{u} b$ al-ittishâlî juga menawarkan dan memberikan pelatihan kepada peserta didik untuk mampu mengarang secara mandiri. Dalam komputer diberikan beberapa topik yang dapat dipilih oleh peserta didik secara bebas, dan mereka kemudian diharapkan mampu untuk mengarang secara bebas tentang topik yang disediakan berdasarkan pengetahuan, pengalaman dan apa yang mereka rasakan dalam kehidupan mereka.

Desain model al-hââub al-ittishâlî dalam hal pencapaian keterampilan menulis sebagaimana yang dijelaskan di atas memberikan peluang kepada peserta didik untuk dapat menuangkan ide atau pikiran mereka baik secara terstruktur maupun secara bebas. Secara terstruktur maksudnya adalah bahwa dalam model ini dimuat materi keterampilan menulis dengan sebuah "topik" pembicaraan dan topik tersebut disertai dengan beberapa kosakata (mufradât) yang berkaitan dengan tema untuk kemudian digunakan oleh peserta didik dalam menuangkan pemikiran mereka.

Sementara itu, latihan untuk menuliskan ide secara bebas maksudnya dalam model ini ialah bahwa peserta didik hanya diberikan sebuah "topik". Mereka bebas untuk mengungkapkan isi pikiran mereka dengan kosakata (mufradât) yang mereka miliki. Model latihan seperti ini dimaksudkan agar mereka terbiasa mendeskripsikan sebuah objek dalam rangkaian kalimat yang dapat dipahami oleh orang lain. Dari uraian di atas dapat diketahui bahwa isi dan muatan model pembelajaran bahasa Arab al-hââub al-ittishâlî yang dirancang ini dapat membantu pendidik untuk dapat mengintegrasikan materi, media, dan metode pembelajaran bahasa Arab, dan model ini juga membantu mereka untuk lebih mudah memberikan pemahaman tentang materi pembelajaran bahasa Arab kepada peserta didik.

Selain itu, model ini juga dapat memberikan motivasi sendiri kepada peserta didik untuk lebih giat dalam mengikuti pembelajaran bahasa Arab. Model al-hââub al-ittishâlî memberikan peluang kepada peserta didik untuk dapat dengan mudah mempelajari bahasa Arab secara mandiri, di dalamnya juga dimuat berbagai model latihan yang dapat dikerjakan oleh peserta didik secara mandiri dalam batasan waktu tertentu dan mereka dapat mengetahui hasil kerja sendiri. 


\section{Simpulan}

Penelitian ini menghasilkan sebuah temuan bahwa model pembelajaran bahasa Arab berbasis Teknologi Informasi dan Komunikasi yang disebut dengan model al-hââub alittishâlî. Model ini dirancang untuk jenjang pendidikan MTs kelas VII. Hasil validasi dari para ahli dan hasil ujicoba menunjukkan bahwa semuanya sepakat kelayakan model pembelajaran yang dirancang termasuk dalam kategori baik. Hal ini dilihat dari sisi materi, kualitas tampilan maupun pengorganisasian.

Model ini dapat saja dipandang sebagai materi pembelajaran bahasa Arab, karena dalam model ini memuat materi pembelajaran bahasa Arab kelas VII secara keseluruhan, mulai dari materi yang berkaitan dengan kosakata (mufradât), materi tentang percakapan (hiwâr), materi tentang bacaan (qirâ'ah), materi menulis (kitâbah), pola-pola kalimat (tarâkîb) sampai pada materi evaluasi dengan berbagai variasinya.

Model al-ĥâsûb al-ittishâlî juga dapat dipandang sebagai media pembelajaran bahasa Arab, karena dapat dijadikan sebagai fasilitas pembelajaran yang dapat membantu peserta didik untuk lebih mudah memahami bahasa Arab. Selain itu, model ini juga dapat meningkatkan motivasi peserta didik untuk lebih giat dalam mempelajari bahasa Arab, karena model ini dapat dioperasikan sendiri oleh peserta didik di luar jam pelajaran seperti di rumah. 


\section{Daftar Rujukan}

Abu Syanab, Maysa', “Tiknulujiya Ta'allum al-Lughah al-“Arabiyah”, dalam Journal alAdab wa al-Tarbiyah, Sudan, Vol. 2, No. 32,2007.

Baso, Yusring Sanusi, Program Multimedia Bahasa Arab. Padang, Prosiding PINBA IMLA, 2013.

Clark, Richard E., "Reconsidering Research on Learning from Media", dalam Journal JSTOR, 1983, Vol. 53, No. 4.

Creswell, E. L, The Design of Combuter Based Instruction. New York: MacMillan Publishing Company, 1998.

Effendy, Ahmad Fuad dan Muhaiban, Bahasa Arab untuk SMU Buku Pedoman Guru. Jakarta: Departemen Pendidikan Nasional, 1999.

Faridi, Abdurrahman, "Inovasi Pembelajaran Bahasa Inggris Berbasis ICT dalam Rangka Meningkatkan Mutu Pendidikan”, dalam Jurnal Lembaran Ilmu Kependidikan Jilid 38, No. 1, Juni 2009.

Hubbard, P., Learner Training for Effective Use of CALL. State College PA: Center for Advance Language Proficiency and Education and Research, 2006.

Schramm, Wilbur, Asas-asas Komunikasi Antar Manusia, Terj. Agus Setiadi. Jakarta: LP3ES, 1977.

al-Ushaili, Abdul 'Aziz Ibrahim, Asâsiyât Ta'lîm al-Lughah al-'Arabiyah li an-Nâthiqîn bi Lughât Ukhrâ. Riyadh: Jami'ah al-Imam Muhammad bin Su'ud al-Islamiyah, 1423 H.

Wane, Made, Strategi Pembelajaran Inovatif Kontemporer. Jakarta: Bumi Aksara, 2009. 